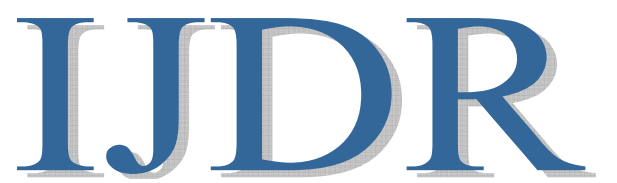

International Journal of Development Research

Vol. 10, Issue, 09, pp. 39857-39863, September, 2020

https://doi.org/10.37118/ijdr.19912.09.2020

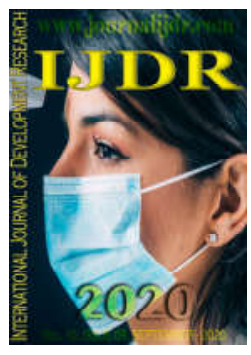

\title{
NARRATIVES OF MATHEMATICS TEACHERS FROM THE FINAL YEARS OF FUNDAMENTAL EDUCATION: THE PEDAGOGICAL PRACTICE IN FOCUS
}

\author{
${ }^{1}$ Neuton Alves de Araújo, ${ }^{2}$ Francisco de Paula Santos de Araujo Junior \\ and ${ }^{3}$ Anna Karla Barros da Trindade
}

\author{
1Universidade Federal do Piauí - UFPI; ${ }^{2}$ Universidade Estadual do Piauí - UESPI; ${ }^{3}$ Instituto Federal do Piauí - IFPI
}

\section{ARTICLE INFO}

\section{Article History:}

Received $29^{\text {th }}$ June 2020

Received in revised form

$18^{\text {th }}$ July 2020

Accepted 22 ${ }^{\text {nd }}$ August 2020

Published online $23^{\text {rd }}$ September 2020

\section{Key Words:}

Mathematics teachers. Narratives.

Pedagogical Practice.

Final Years of Elementary School.

*Corresponding author: Neuton Alves de Araújo,

\begin{abstract}
The aim of this study is to investigate the pedagogical practice of mathematics teachers from the final years of elementary school in the Municipal Public School of Teresina-PI, in effective teaching activity, based on the narratives of these teachers. This is an empirical research with a qualitative approach. In view of the understanding that pedagogical practice is inseparable from the teaching professional trajectory and in view of the nature of this research, narratives have been used, which have been shown to be appropriate because they enable interlocutors to report their personal perceptions, their most intimate in addition to other experiences that have marked (or have been marking) his professional career. The data produced by the narrative interview and selected for this study, were analyzed in the light of the theoretical framework of Content Analysis from the perspective of Bardin. It was found that the process of critical reflexivity about the practice, constantly experienced by teachers, collaborators of this study, enabled the understanding and rational analysis of their teaching action in the perspective of better systematizing it and making it operational. It also allowed these teachers to develop, based on this critical posture and the perception of the nature of the pedagogical action, knowledge related to their profession, considering that their practice, due to its situated, historical and social character, went beyond the mere application of techniques and content transmission.
\end{abstract}

Copyright (C) 2020, Neuton Alves de Araújo et al., This is an open access article distributed under the Creative Commons Attribution License, which permits unrestricted use, distribution, and reproduction in any medium, provided the original work is properly cited.

Citation: Neuton Alves de Araújo, Francisco de Paula Santos de Araujo Junior and Anna Karla Barros da Trindade. 2020. "Narratives of mathematics teachers from the final years of fundamental education: the pedagogical practice in focus”, International Journal of Development Research, 10, (09), $39857-39863$.

\section{INTRODUCTION}

This text brings and discusses the results of a research involving mathematics teachers from the final years of elementary school in the Municipal Public School of Teresina - PI, in effective teaching activity, with the objective of investigating their pedagogical practice, based on their narratives. According to Ferreira (2003), based on Silva (1998), until the mid-1980s, little had been written and researched on teacher training and even less on the training of mathematics teachers in Brazil. However, from the last two decades this theme has started to be consistently outlined and has become one of the most active areas of research. The teacher (or future mathematics teacher) began to be seen as someone who thinks, reflects on his pedagogical practice, whose meanings need to be recognized. More than a useful "piece" to the system, it started to be considered as an important element in the teaching and learning process. This trend, although only incipient in Brazil, in the 1980s, appears and develops strongly in different parts of the world. Even though, timidly, Brazil is also beginning to transform its research paradigm. It is the paradigm of the "thinking of the teacher" that slowly seeks its space within the scope of research on the formation of mathematics teachers. In view of this reality, teacher training programs began to be rethought, leaving aside a meaning that the teacher would merely apply techniques designed and produced by specialists for their pedagogical practice, a paradigm that Schön (1995) called “ technical rationality ". Having made the comments, in addition to the introduction, this text was structured with the sections: methodological aspects; pedagogical practice of Mathematics teachers: some theoretical reflections; analysis and discussion of the pedagogical practice of mathematics teachers from their narratives; final considerations.

Methodological aspects: This study is a qualitative investigation because it corroborates the reflections of Chizzoti (2006, p. 76), by explaining that,

Researchers who have adopted this guideline have removed themselves from irregularities to dedicate themselves to the analysis of the meanings that individuals give to their actions, in the ecological environment in which they build their lives and their relationships, to the understanding of the meaning of the actions and decisions of social actors or, then, of the inseparable bonds of 
particular actions with the social context in which they occur.

Thus, when considering the objective of this study, already presented, we understand that research of this nature seeks to show that social and interpersonal relationships are complex, contradictory, original and unpredictable. Thus, for clarifications on this research approach, we turn to Minayo (1994, p. 24) to complement that:

Researchers who follow this trend are not concerned with quantifying, but with understanding and explaining the dynamics of social relations, which, in turn, are depositories of beliefs, values, attitudes and habits. They work with experience, with experience, with everyday life and also with the understanding of structures and institutions as a result of objectified human action. In other words, from this point of view, language, practices and things are inseparable.

It is evident, therefore, that qualitative research is not concerned with the quantification of data - it is not excluded from the latter, depending on the data that may be of interest but how they collaborate to understand the phenomenon. Thus, in this research, the data collected consist of descriptions of people, situations, events or places, configuring that the description is fundamental for the development of qualitative research and must pay attention to the greatest number of relevant aspects present in the studied situation. Thus, in view of the understanding that the pedagogical practice is inseparable from the teaching professional trajectory and in view of the nature of this research, we decided to use the narratives, which have been shown to be quite appropriate, since the choice of an approach is more function of the investigative reality than of the personal interest as a researcher. They are appropriate, too, because they allow interlocutors to report their personal perceptions, their most intimate feelings in addition to other experiences that have marked (or have been marking) the interlocutors' professional trajectory. As Nóvoa (1992, p.10) says, "this profession needs to be said of and told: it is a way of understanding it in all its human and scientific complexity" and with this aim our intention is to listen, record the mathematics teachers' narratives and experiences. In this regard, Bolívar (2002, p. 107 ), adds that, in the narratives, the world of the subjects is manifested and the personal stories of the experience allow:

[...]. make an inventory of professional experiences, knowledge and skills; at the same time, when recovering, biographically and narratively, the subject to be formed based on his experiences and memories of the past in the present - they become a training methodology.

Thus, we understand that through narratives, we are giving voice to teachers, as a way to understand their personal and professional path. For Nóvoa (1992, p. 17), "it is impossible to separate the professional self from the personal self". Therefore, we affirm that, in the process of reflecting on their life path, teachers manifest their subjectivity and interpret their actions at the individual and collective level, seeking new meanings for the construction of their professional identity that, directly or indirectly, led to the discussion and consideration of pedagogical practice. In this sense, narratives allow the teacher, by telling his life story, to reveal his desires as well as his expectations regarding the teaching profession and life itself. In order to carry out the empirical study, through the application and questionnaires, we opted for the delimitation of a sample of Mathematics teachers from the Municipal Public School of Teresina-PI that met the prerequisites: to be an effective teacher of the network of the final years of elementary school. regular education; have a Full Degree in Science with a Mathematics Degree or a Full Degree in Mathematics and have at least four years of teaching activity in Mathematics with the final years of regular elementary school, thus making a total of 13 (thirteen) teachers. In order to guarantee anonymity, we chose to maintain the confidentiality of the names of teachers, collaborators in this study. For this, we use codenames (Prisma, Hypotenuse, Polygon, Trapezoid, Sine, Tangent, Cosine, Algebra, Exponent, Estimate, Baskara, Pythagoras, Tales) and, consequently, we do not mention the names of the schools where each one works. And, as a way of producing data, we work with the narrative interview. We clarify that this technique allowed us to detect the interviewee's attitudes, motivations and meanings, since, from the defined interview script, the teacher was free to spontaneously express his relationship, his opinions and his feelings about his pedagogical practice in the final years of elementary school. That said, in view of the set of information relevant to understanding the object of the research, we consider it relevant to emphasize that the data produced by the narrative interview and selected for this study were analyzed in the light of the theoretical framework of Content Analysis (BARDIN, 1977 ), as one of several ways to interpret a text. Content analysis, according to Bardin (1977, p. 9), is defined as "[...] a methodological set [...] that applies to extremely diverse discourses". In accordance with this perspective, the analysis procedures took place in three stages: the first was pre-analytical (organization of the material to be studied); the second, the analytical (study of the material for coding, classification and categorization) and, the third, the inferential interpretation (reflection, in order to establish relations with the researched reality, making the necessary inferences).

\section{Pedagogical practice of Mathematics teachers: some theoretical reflections}

Brito (2005) analyzes the training of teachers and observes serious criticisms in relation to the training models, as well as verifying the design of new pillars for the qualification of the teacher, based on the conception that the teaching practice constitutes a social practice. In the understanding, this "[...] conception postulates that the professional role of the teacher transcends the status of technician, responsible for the transmission of knowledge". (BRITO, 2005, p. 45).Dessa forma, em conformidade com as observações da autora em tela, consideramos pertinente repensar a atuação e a formação dos professores, de modo particular, a do professor de Matemática. Returning to Brito's analysis, what can be seen is that teacher training practices have been built according to the logic of technical rationality, in which the teacher is considered a technician who rigorously applies the rules that emerge from scientific knowledge. In the sense of Pavão (2006, p. 162), "in this tradition of teacher training, what has been verified in the educational field is a profound distance between scientific knowledge and the world of practice". In the case of mathematics, the situation seems to be even more serious. What we see in the vast majority of schools, from our teaching experiences, is this science being passed on without the concern of establishing links with reality or with the student's daily life, that is, mathematics is not being 
contextualized. In making a thoughtful analysis of this problem, D’Ambrósio (1996, p. 119) emphasizes that:

Formal education is based either on the mere transmission (theoretical teaching and lectures) of explanations and theories, or on training (practical teaching with repetitive exercises) in techniques and skills. Both alternatives are totally wrong in view of the most recent advances in our understanding of cognitive processes. One cannot assess cognitive skills outside the cultural context. But it is known that cognitive ability is a characteristic of each individual.

According to Contreras (2002), as a technician, the teacher came to be seen as a reflective professional (researcher / reflects on practice) and, later, as a critical intellectual (selfreflection on ideological distortions and institutional constraints). In fact, according to this author (ibid.), It was Giroux who best developed the concept of teacher as a critical intellectual. This concept differs from the reflective one, in that it does not refer only to the type of meditation that can be done by teachers about their practices and the uncertainties that they cause, but "also supposes 'a form of criticism' that would allow them to analyze and question the structures institutions in which they work". (CONTRERAS, 2002, p. 162). In the light of Brito's discussion (2005, p. 46), these new concepts emerged based on the assumption that "the teacher qualification must articulate theory and practice, valuing the critical-reflexive attitude as a vital element in a pedagogical activity situated as a social practice" . And as a link between theory and practice in the formation and professional development of the mathematics teacher there is "research as a daily attitude, seeking in practice to rethink theory and in theory to rethink practice" (D'AMBRÓSIO, 1996, p. 80-81). And so, in this context, the concept of reflective teacher emerges. In order to discuss the reflective paradigm, we evoke the thoughts of some theorists.

For Alarcão (2007), the notion of reflective teacher is based on the awareness of the capacity for thought and reflection that characterizes the human being as creative and not as a mere reproducer of ideas and practices that are external to him. It is fundamental, in this concept, the notion of the professional as a person who, in professional situations, so often uncertain and unforeseen, acts in an intelligent and flexible way, situated and reactive. In the view of Fiorentini and Castro (2003), without reflection, the teacher mechanizes his practice, falls into the routine, passing the work over and over, reproducing what is already ready and what is more accessible, easy or simple. For these same authors, having as theoretical support Saviani (1980), to reflect means to produce, in a meticulous way, meanings about what we do and are; it is the act of resuming, reconsidering the available data, revising, searching in a constant search for meanings. It is to examine carefully, to pay attention, to analyze carefully. In addition, "[...] the professional who reflects on the action, becomes a researcher in the practical context" (SCHÖN, 2000, p. 35). In this perspective, we understand that, for this researcher, action is conducive to research and investigation, because in the face of any new situation, the teacher must act to solve it. In fact, reflection implies:

[...]. the conscious immersion of man in the world of his experience, a world full of connotations, values, symbolic exchanges, affective correspondences, social interests and political scenarios. Academic, theoretical, scientific or technical knowledge can only be considered an instrument of the processes of reflection if it is significantly integrated, not in isolated portions of semantic memory, but in more generic thought schemes activated by the individual when interpreting the concrete reality in which he lives and when you organize your own experience. (PÉREZ GÓMEZ, 1995, p. 103).

Pimenta (2005), corroborating the thoughts of this theorist, points out that teaching as a reflexive practice has established itself as a trend in educational research, pointing to the valorization of the processes of production of teaching knowledge based on reflexive practice. Still on this type of practice, the same author, supported by the ideas of Zeichner (1993), emphasizes the importance of preparing teachers to assume a reflexive attitude towards their teaching and the social conditions that influence it. According to the author, the defense of a perspective of teachers as reflective practitioners leads Zeichner to reject a view of top-down approaches to educational reforms, in which teachers passively apply plans developed by other social, institutional and / or political actors. Ideas about the concept of reflective teacher, or rather, reflective thinking - "the vehicle through which transformation takes place" - emerged in the second decade of the last century, with Dewey, American philosopher, psychologist and pedagogue, who strongly influenced thinking contemporary pedagogical, proposing the "five phases of reflective thinking" (DOLL JR, 1997, p. 154). Dewey believed that the search for the reflective teacher should be the search for a balance between act and thought. These ideas were taken up and multiplied from the $80 \mathrm{~s}$, with Schön, suggesting a model of "reflective practice", or better, reflections of the individual on the lived experience.

In this same perspective, Carvalho (2006), based on Dewey (1959), understands that reflective thinking requires the cultivation of favorable attitudes when developing the meaning-building process, for example:

a) Open spirit or open mindedness for the new. In this case, it refers, for example, to situations of the type: active desire to pay attention to all divergent, and even dissenting, voices that participate in the process of reflection in overcoming conflicts; the desire to pay attention to facts from different sources - in the classroom, give a voice to the student, be aware of the different hypotheses raised by him, as alternative moments / possibilities;

b) With all the heart or the interest absorbed: it means, for example, to be turned, with all enthusiasm, to the interest of solving the embarrassing situations that the subject is faced with;

c) Responsibility: it turns to the subjects' ability to be intellectually responsible, examining the consequences of a projected step; to take these consequences for themselves and to pursue educational and ethical intentions proper to teaching conduct, as we know that "[...] intellectual responsibility ensures integrity, that is, the consistency and harmony of belief". (DEWEY, 1959, p. 40 apud CARVALHO, 2006, p. 18).

In the sense of Schön (1995), practice occupying a prominent position in the training of teachers and understood as a process 
of investigation and dialogue with reality must promote a movement of action and continuous reflection on teaching action, that is, reflection on the action will generate a new action, which will generate a new reflection and so on. The movement described: "knowledge in action, reflection in action and reflection on action and on reflection in action" is suggested by this author for the "training of teachers as reflective professionals". In this sense, we agree with Freire (1996, p. 39) when he says that

[...]. through reflection on practice, naive curiosity, perceiving itself as such, becomes critical ... That is why, in the permanent training of teachers, the fundamental moment is that of critical reflection on practice. It is by thinking critically about today's or yesterday's practice that the next practice can be improved.

Regarding these issues, Nóvoa (1995) goes further, emphasizing that the process of critical-reflective training implies producing the teaching profession (professional development), producing the teacher's life (personal development) and producing the school (organizational development).

In view of all these positions regarding the concept of reflection, we understand that it is seen as a process in which the teacher analyzes his practice, compiles data, describes situations, elaborates theories, implements and evaluates projects and shares his ideas with peers and students, stimulating group discussions. In fact, we understand reflection as a possible path of ruptures, which seeks indexes to better understand the school routine and develop pedagogical actions that integrate the student and the teacher more in the teaching-learning process. That is, it appears as part of the professional training process, in which the teaching knowledge (to be discussed in the next topic) is mobilized, problematized and re-signified by the teachers. Resignification is nothing more than the creative process of attributing new meanings based on what is already known, since, in the sense of Fiorentini and Castro (2003, p. 128), “[...] it is in this process of producing meanings and reframing knowledge and actions that we become teachers.".

\section{Analysis and discussion of the pedagogical practice of mathematics teachers from their narratives}

The ways of teaching, historically practiced by schools, express the purposes linked to the different moments of development of the historical production process of society. The educational process highlights, throughout history, moments when only the teacher taught and only he was at the center of the pedagogical process (traditional pedagogy). At other times, the student was seen as the core of the teachinglearning process (new pedagogy). There is also the moment of action planning, when neither the teacher nor the student were at the center of the educational process (technicist pedagogy), emphasizing sometimes knowledge, now the student, now the teacher, now the techniques. These practices led to the fragmentation and neutrality of "how to teach", especially with regard to the teaching of mathematics, as shown by studies developed by researchers in the field of mathematics teaching, among others, Valente (2007), Damazio (1996), D ' Ambrósio (1996, 1999a, 1999b), Miorim (1998), Fiorentini (1995), moving away from a reflective pedagogical practice that advocates education as a social practice and as an instrument of emancipation, committed to democratization and training, teacher and student, as agents of change. In this context, we understand pedagogical practice as a dimension of social practice that seeks the unity of theory-practice and that has two sides: the theoretical and the objective, as Veiga (1989) tells us. The first is represented by a set of ideas formed by pedagogical theories, with the intention of ideally elaborating or transforming the raw material. The objective side is constituted by the set of means, the way in which the pedagogical theories are put into practice by the teacher, the purpose of which is the real, objective transformation, in order to satisfy a certain human need. However, "[...] when priority is placed on theory, one falls into the idealistic position [...]". The reverse also creates distortions, as a practice without theory does not know what it practices, "[...] promoting activism, practicalism or utilitarianism [...]". (VEIGA, 1989, p. 17).

Thus, in this section of the study, we started to analyze data produced through narrative interviews that give us evidence of the characterization of the pedagogical practice of Mathematics teachers from the 6th to the 9th grade of elementary school. Reflecting on the ideas already discussed, we raised the question to the 13 (thirteen) interlocutors of the research: About your pedagogical practice in Mathematics, how do you characterize it? For that, we expose the following testimonies:

Considering the historical process I went through, my practice in mathematics has undergone many changes. Currently, I consider myself a teacher who acts based on contextualization and who works valuing the content that students bring. I think of the hypothesis that students have a knowledge and that knowledge needs to be respected and some limits must also be respected, so treatments cannot be universal, they have to be differentiated treatments, at least, if not individualized thinking studentstudent, but at least categorically grouping these students, so that we can do a better job. So, I am no longer concerned with meeting the demand for content, making the student not only have knowledge of mathematical techniques, but that he has a background and is able to interact with the content, that is, that he can gain autonomy in their studies. This is a perspective that I think is important; is that the student, from the moment he gains autonomy in his studies, can even recapture subjects that were lost in his past; he can go back, re-study and improve his knowledge, regain the knowledge that happened to go unnoticed during his studies (Exponent).

It seems funny, but I think I have changed little, because I am aware of it and I evaluate my teaching practice as being traditional. I still haven't managed to make teaching practice something contemporary, modern, innovative, I still work in the traditional perspective (Prisma).

I see great growth and positive, optimistic. [...] I always try to find a methodological strategy, a differentiated alternative within the area, trying to take learning to the student. [...] In fact, it hasn't changed much since I started until now. I have ten years in the classroom and always aim to discover a meaningful way for the student to learn, to seek research, to seek an application abroad, to seek meaning with what he is learning (Tangent). 
Today I work a lot with the students' ideas, because before I didn't work as much as I am working today. I learned that when we enter the classroom, ask for silence and start explaining a subject, this is boring for them, so I try to work on a subject that is involved in their daily lives; I try to contextualize the contents of mathematics and I also take great advantage of the students' concepts, of how they responded, for example. I ask them to say how they did it; sometimes I call them and they already have a better way to explain it, because sometimes our students have and come to a solution in a more practical way and in an easier way to explain it to their colleagues. [...] I take advantage of this knowledge that students bring and pass on to their colleagues; I don't work only with formulas ... I try hard to work the way they responded, taking into account their reasoning (Estimate).

[...] I characterize myself as a current teacher, a reflective teacher, open to knowledge and respect for any position of friend of mine, however, even though I do not agree with certain positions. I try to streamline my classroom practice, I also seek to seek knowledge in other areas. This issue of interdisciplinarity, which has been preached so much in recent years, in my practice, I had been preaching this for a long time, because I made this connection with other areas and I even remember an experience when a student asked me: Why negative number ? Why positive number? I told him that this is just a symmetry. And what was symmetry? It is the distance between two points, that is, it is the equidistance and compared to the human body, the distance between the tip of the middle thumb and the spine on the left side is the same on the right side, so I tried to put it for the student who it was a reference and from there I would do the operations, when you subtract, in fact the subtraction does not exist literally, you add a number to the symmetric of the other. It is a positional value. So I always looked for it there, I sought knowledge in other areas to make it more attractive and I have been successful. [...]. (Trapezoid).

We find in the statements of the interviewees the daily rethinking of the pedagogical practice, in the exercise of researching and reflecting on their teaching action, as referred by Pimenta (1997), an opportunity in which they build knowledge that allows them to improve their teaching practice. In this regard and in this perspective of the group of deponents, we only except Professor Prisma, who still insists on a traditional practice. The others are in line with this conception, including the appreciation of the student's prior knowledge, contextualization and interdisciplinarity as resources that appear with great frequency in the classes of Mathematics teachers.

When analyzing teachers' classes, contextualization emerges as the resource most used by teachers. Just to illustrate, in a class by Professor Tangente, with 6 th graders, she asked students to research the prices of the food they eat most and to build a table exposing the data. In the next class, the teacher worked on operations with natural numbers, which we understand, pedagogically considering, to be a way of working with the student's reality, making the content acquire meaning and relevance for them, valuing the action between teacher, student and social reality. Returning to the teachers' speech about their pedagogical practices and taking into account the free observations made, from an analytical point of view, we classify them in two perspectives: "repetitive" and uncritical pedagogical practice and reflective and critical pedagogical practice, according to Veiga (1989). In repetitive pedagogical practice, a weak intervention of conscience means that the teacher does not recognize social meaning in his actions. He is converted into an instrument handler, what they lack is an awareness of the purposes of education, of its relations with society, of the means necessary for carrying out educational activities and of its historical mission.

This perspective of practice focuses on the profile of a teacher who acts privileging only how to do, through repetition, presenting the contents in a mechanized way, adhering to a utilitarian practice, based on a prescriptive, normative characteristic and based on pre-established standards. In fact, the teacher assumes the position of teaching technologist, as he places himself " $[. .$.$] on the margins of the activity he performs,$ establishing relationships only between the operations he performs and not between the people involved". (VEIGA, 1989, p. 19). This type of pedagogical practice, especially in Professor Prisma's classes, was evidenced through actions such as, for example, reaching the classroom and barely greeting the students, then passing the call and immediately going to the board to present a list exercises with problem situations. The teacher himself solved all exercises, all problem situations, without establishing any connection with the student's daily life. He explained item by item, with virtually no student participation. At the end of the explanation, he asked if the students had any questions to ask regarding the content exposed, but the students remained silent. The teacher said goodbye and then left the room. And so, the class ended. Analyzing the behavior of Professor Prisma, it is seen that he conceives teaching as a simple transmission of information, disregarding the historical and contextual elements, a fact that fragments the contents, since they are taught as an end in themselves and not as a means for provide the development of the comprehension of the totality, as exercise of citizenship, inclusive. This teacher behavior converges to what Imbernón (2005) refers to when opposing the idea of the teacher as a technician who develops or implements prescribed innovations, on the contrary, he defends that the teacher must become a critical, active and participative professional, in order to make the teaching and learning process more dynamic and more flexible.

In this sense, we agree with Rios (2001, p. 26), when affirming and defending that the class is not limited to the space of the "classroom", but must be thought and carried out as "[...] the adventure of the knowledge, the relationship with reality [...]", in the involvement and dialog between students and teachers, thus expressing the complexity that involves the task of teaching. In other words, to paraphrase Freire (1996), the teacher must know that teaching is not transferring knowledge, but creating possibilities for his own production or construction. In addition, we must always be open to inquiries, curiosity, questions from students and their inhibitions, being a critical and inquiring being. Regarding the second perspective of pedagogical practice, the reflexive one, this focuses on the unity between theory and practice, which, according to Veiga (1989), implies associating knowledge and doing, reconciling what the teacher thinks and what he does, counting on the accentuated presence of conscience, reaching a creative activity and, finally, providing a moment of analysis and criticism of the situation and a moment of overcoming and 
proposing action. Along the same lines of thought, Carvalho (2006, p. 14) clarifies that:

The reflexive pedagogical practice, due to its high degree of reflexive awareness, or the high level of awareness of praxis, is characterized by being a mature and conscious option of the individual who wants and who is interested in knowledge as one of the ways to appropriate of the objects of the world and to understand them situated in the world, in the light of collective-action-reflectionreflection, repeated and constant. As a dimension of the broader social practice, reflective pedagogical practice is characterized, above all, by the collective work between curious, restless and dissatisfied subjects with the results of their own work and who suspect that the group's diversity is a point to explore for enrich their own individuality. Finally, reflective pedagogical practice is characterized by its emancipatory character and as a source that generates new knowledge and / or new theories.

Thus, through the ideas presented by the authors, the teaching profile that fits in this context is that of the teacher as a social agent, which develops within a critical and emancipatory education that requires, according to Veiga (1989), the construction and the mastery of solid knowledge from professional training, disciplinary, curricular and experiential knowledge. Therefore, in most of the reports of the interviewed teachers, many elements are in line with the ideas concerning reflective pedagogical practice, as it is possible to check through the fragments of the statements of the interviewees, such as Professor Tangente who expresses: “[...] I seek always find a methodological strategy, a differentiated alternative within the area, seeking to take the learning to the student. " (Interview); or as Professor Expoente says: "[...] I consider myself a teacher who acts based on context and who works valuing the contents that students bring." (Interview). Professor Báskara, in this regard, reveals: "[...] I try to reflect in relation to how to introduce a certain subject for students [...]." The Professor Estimate also puts her testimony: "[...] I try very hard to work the way they responded, taking into account their reasoning." (Interview). And finally, Professor Trapézio adds: "[...] I characterize myself as a current teacher, a reflective teacher, open to knowledge [...]." (Interview). In this context, teaching practice becomes the vital nucleus of the production of new knowledge, within praxis, in which experiential knowledge and culture are erected and constitute the center of teaching knowledge. Therefore, we reinforce the idea that experiential knowledge is produced through reflective practice, since the teaching experience consists of a space that allows the teacher to generate and produce knowledge.

\section{Final considerations}

From the analysis of the contributions presented by the researchers who served us as a theoretical framework, indicated in the sections of this study and the data produced through the narrative interview, we seek to investigate the pedagogical practice of Mathematics teachers in the final years of Elementary School of the Municipal Public Network Teresina-PI, in effective teaching activity. The search to achieve this goal required us to be constantly vigilant about the investigative look, in order to try to perceive in the analyzes new interpretations that surpassed anticipated readings, the result of reflections produced by those who built intimate familiarity with the research field. We admit that, despite this effort of self-surveillance, we are aware of the incompleteness of our analyzes. Therefore, the findings of this research allowed us to ascertain that the initial training of Mathematics teachers left gaps that were only filled, in part, by the teaching action. The classroom routine has been contemplating teachers with knowledge acquired through interaction with other peers and policies that permeate the school scenario. According to the narrative interview reports, the teachers did not feel prepared to deal with the specificities of the teaching action at the beginning of their careers. We attribute this fact to the structure of undergraduate courses, which still follow the model in which specific subjects stand out to the detriment of pedagogical subjects, instead of an articulation between both, since the knowledge of the subject to be taught is not enough for someone to be a math teacher.

We understand that teacher training courses, in general, should enable teachers, above all, to overcome the model of technical rationality to ensure the basis for reflexivity in their training and professional performance, as pointed out by Contreras (2002), Pimenta (2005), Ghedin (2005), among other theorists. However, in order for this to happen, we emphasize the importance of defining the true objective of undergraduate courses in mathematics. At the end of a course, the teacher receives a diploma that grants him the qualification of Licensee in Mathematics, however, we observe in the narratives that the skills and competences acquired throughout the course do not qualify them for the training necessary to exercise teaching, due to being several gaps without being filled. Faced with this reality, the idea that the Bachelor's Degree in Mathematics is the right moment for the construction and rethinking of the conceptions of future teachers in a way that leads to a truly meaningful mathematical learning is resumed, and the university is understood as a space for the production of knowledge and significant learning experiences. In the light of the analysis framework, we found that the process of critical reflexivity about the practice, constantly experienced by the participants of this study, enabled the teacher to understand and rationally analyze his teaching action in the perspective of better systematizing and operationalizing it. It also allowed these teachers to develop, based on this critical posture and the perception of the nature of the pedagogical action, knowledge related to their profession, considering that their practice, due to its situated, historical and social character, went beyond the mere application of techniques and content transmission. Finally, we emphasize, therefore, that from the perspective of the teachers themselves, we were able to better understand the problems that these teachers trained by the Federal and State Universities of Piauí experienced (and experience) in teaching, thus providing valuable clues for both the curricula of the initial and continuing training programs in the Brazilian / Piauí reality as to better understand the process of learning to teach, which is not limited, as seen in this study, to the model of technical rationality.

\section{REFERENCES}

ALARCÃO, I. Professores reflexivos em uma escola reflexiva. São Paulo: Cortez, 2007.

BARDIN, L. Análise de conteúdo. Lisboa: Edições 70, 1977.

BOLIVAR, A. (Org.). Profissão professor: o itinerário profissional e a construção da escola. Bauru, SP: EDUSC, 2002. 
BRITO, A. E. Sobre a formação e a prática pedagógica: o saber, o saber-ser e o saber-fazer no exercício profissional. Linguagens, Educação e Sociedade. Teresina. n. 12, p. 4552, jan./jun. 2005.

CARVALHO. M. A. de. A prática docente: subsídios para uma análise crítica. In: MENDES SOBRINHO, J. A. de C; CARVAlHO, M. A. de. (Org.). Formação de professores e prática docentes: olhares contemporâneos. Belo Horizonte: Autêntica, 2006. p. 11-30.

CHIZZOTTI, A. Pesquisa em ciências humanas e sociais. São Paulo: Cortez, 2006.

CONTRERAS, J. Autonomia de professores. São Paulo: Cortez, 2002.

D’AMBRÓSIO, U. A história da matemática: questões historiográficas e políticas e reflexões na Educação Matemática. In: BICUDO, A. V. (Org.). Pesquisa em Educação Matemática: concepções e perspectivas. São Paulo: Editora UNESP, 1999b. p. 97-115.

D’AMBRÓSIO, U. Educação Matemática: da teoria à prática. Campinas: Papirus, 1996.

D’AMBRÓSIO, U. Educação para uma sociedade em transição. Campinas: Papirus, 1999a.

DAMAZIO, A. Ensino da Matemática: retrospectiva histórica. Revista Ciências Humanas. Criciúma, v. 2, n. 2, p. 73-88, jul./dez. 1996.

DOLL JR, W. E. Currículo: uma perspectiva pós-moderna. Porto Alegre: Artes Médicas, 1997.

FERREIRA, A. C. Um olhar retrospectivo sobre pesquisa brasileira em formação de professores de matemática. In: FIORENTINI, D. (Org.). Formação de professores de Matemática: explorando novos caminhos com outros olhares. Campinas: Mercado de Letras, 2003. p. 19-50.

FIORENTINI, D. Alguns modos de ver e conceber o ensino da Matemática no Brasil. Revista Zetetiké. Ano. 3, n. 4, nov., p. 1-37. Campinas: FE - CEMPEM, 1995.

FIORENTINI, D.; CASTRO, F. C. Tornando-se professor de Matemática: o caso de Allan em prática de ensino e estágio supervisionado. In: FIORENTINI, D. (Org.). Formação de professores de Matemática: explorando novos caminhos com outros olhares. Campinas: Mercado de Letras, 2003. p. 121-156.
FREIRE, P. Pedagogia da autonomia: saberes necessários à prática educativa. São Paulo, SP: Paz e Terra, 1996.

GHEDIN, E. Professor reflexivo: da alienação da técnica à autonomia da crítica. In: PIMENTA, S. G.; GHEDIN, E. Professor reflexivo no Brasil: gênese e crítica de um conceito. São Paulo: Cortez, 2005. p. 129-150.

IMBERNÓN, F. Formação docente e profissional: formar-se para a mudança e a incerteza. São Paulo: Cortez, 2005.

MINAYO, M. C. de S. (Org.). Pesquisa social: teoria, método e criatividade. Petrópolis: Vozes, 1994.

MIORIM, M. A. Introdução à História da educação Matemática. São Paulo: Atual, 1998.

NÓVOA, A. Vidas de professores. Porto: Porto Editora, 1992.

PAVÃO, Z. M. Formação do professor-educador matemático em cursos de Licenciatura. Revista Diálogo Educacional, v. 6, n. 18, p. 161-168, maio/ago. 2006.

PERÉZ GÓMEZ, A. O pensamento prático do professor: a formação do professor como profissional reflexivo. In: NÓVOA, A. (Coord.). Os professores e a sua formação. Lisboa: Dom Quixote, 1995. p. 93-114.

PIMENTA, S. G. (Org.). Saberes pedagógicos e atividade docente. São Paulo: Cortez, 2005.

PIMENTA, S. G. Didática e formação de professores: percursos e perspectivas no Brasil e em Portugal. São Paulo: Cortez, 1997.

RIOS, T. A. Compreender e ensinar: por uma docência da melhor qualidade. São Paulo: Cortez, 2001.

SCHÖN, D. A. Educando o profissional reflexivo: um novo design para o ensino e a aprendizagem. Porto Alegre: Artes Médicas Sul, 2000.

SCHÖN, D. A. Formar professores como profissionais reflexivos. In: NÓVOA, A. (Coord.). Os professores e a sua formação. Lisboa: Dom Quixote Ltda, 1995. p. 93114.

VALENTE, W. R. História da Matemática Escolar no Brasil (1730 - 1930). São Paulo: Annablume: FAPESP, 2007.

VEIGA, I, P. A. A prática pedagógica do professor de didática. São Paulo: Papirus, 1989. 